\title{
Statins as a Candidate of Drugs for Intracranial Aneurysm Treatment
}

\author{
Keiichi Tsuji1', Tomohiro Aoki², Miyuki Fukuda3 ${ }^{3}$ Kazuhiko Nozaki1 ${ }^{*}$ \\ ${ }^{1}$ Department of Neurosurgery, Shiga University of Medical Science, Shiga, Japan \\ ${ }^{2}$ Innovation Center for Immunoregulation Technologies and Drugs (AK Project), Kyoto University Graduate \\ School of Medicine, Kyoto, Japan \\ ${ }^{3}$ Department of Neurosurgery, Kyoto University Graduate School of Medicine, Kyoto, Japan \\ Email: tsujikei@belle.shiga-med.ac.jp, tomoaoki@kuhp.kyoto-u.ac.jp, mfukuda@kuhp.kyoto-u.ac.jp, \\ noz@belle.shiga-med.ac.jp
}

Received 2 May 2014; revised 4 June 2014; accepted 12 June 2014

Copyright (C) 2014 by authors and Scientific Research Publishing Inc.

This work is licensed under the Creative Commons Attribution International License (CC BY).

http://creativecommons.org/licenses/by/4.0/

(c) (i) Open Access

\section{Abstract}

The treatment for intracranial aneurysm (IA) is socially important because of poor outcome posed by subarachnoid hemorrhage after rupture. Further, the incidence of IAs in general public is high and, indeed, in developed countries many IAs are incidentally found through brain check. However, to date, options for treatment of IAs to prevent rupture are quite limited only to surgical procedures such as microsurgical clipping and endovascular coiling. Taking into account unavoidable risks of complication from surgical interventions and numerous aneurysm careers without treatment, less invasive medical therapies should be established. In human IA lesions, the presence of inflammatory responses, such as expressions of pro-inflammatory mediators and infiltration of inflammatory cells, have been reported, which suggests the involvement of inflammatory responses in the pathogenesis of IA. Recent experimental studies using rodent models have revealed the crucial role of inflammatory responses mediated by NF- $\kappa$ B activation in IA formation and progression and supported the notion that IA is an inflammatory disease affected intracranial arteries. To find out a candidate drug for IA treatments, the effect of several drugs with anti-inflammatory and anti-NF- $\kappa$ B actions on IA progression has been examined using rodent models and revealed the excellent inhibitory effect of statins (HMG-CoA reductase inhibitors) on IA progression. Based on these findings, the case-control study was recently carried out enrolling patients with unruptured or ruptured IAs to examine the effect of statin usage on rupture. This study revealed the significant differences in the ratio of statin usage between two groups and notably the remarkable reduction of risk of rupture of pre-existing IAs under statin usage at the adjusted odds ratio of 0.30. Recent laboratory and clinical studies make considerable achievement toward the future development of drugs for IA treatment and especially suggest the potential of statins as a candidate.

\footnotetext{
*Corresponding author.
} 


\section{Keywords}

\section{Inflammation, Intracranial Aneurysm, NF- $\kappa$ B, Statin, Subarachnoid Hemorrhage}

\section{Introduction}

Recent advance in medical technology greatly contributes to improving the outcome of various diseases including intracranial diseases. However, even today, subarachnoid hemorrhage still poses a high risk of mortality and severe morbidity despite intensive treatments [1]. The cause of subarachnoid hemorrhage is, in most cases, rupture of pre-existing intracranial aneurysm (IA), a lesion with regional bulging of intracranial arteries histologically characterized by the disrupted internal elastic lamina and the degeneration of media. IA is a common disease in general public with prevalence between 1 to 5 percent [2] [3]. Indeed, many IAs are incidentally found before rupture through imaging tests by CT or MRI in developed countries. However, to date, there is no medical treatment available for these incidentally found IAs except for surgical procedures, microsurgical clipping and endovascular coiling, to prevent rupture and resultant subarachnoid hemorrhage [4]-[6]. Considering the social loss due to a resultant subarachnoid hemorrhage after rupture, unavoidable risk of complication in surgical procedures and the high incidence of IAs, a new medical treatment for preventing rupture of pre-existing IAs should be developed.

In this review, we briefly summarize the proposed mechanisms underlying IA formation especially focused on NF- $\kappa \mathrm{B}$-mediated inflammation and discuss its potential as a therapeutic target for treatment. Further, we introduce the future prospection for the development of drugs for IA treatment.

\section{NF- $\kappa$ B as a Potential Therapeutic Target for IA Treatment}

Amounts of studies from human specimen have been done and revealed the presence of inflammatory responses, such as expressions of pro-inflammatory factors and infiltration of macrophages, in IA lesions suggesting the involvement of inflammation in the pathogenesis of IAs [7]-[17]. Further, experimental studies mainly using animal models [18] [19], in which IAs are induced by increase of hemodynamic stress through one side of carotid ligation (this procedure increases blood flow at contralateral side in intracranial arteries) and induced hypertension, have clarified the involvement of active and long-lasting inflammatory responses in the pathogenesis of IA formation and progression and supported the findings from human studies [11] [20]-[27]. In these series of studies, the crucial role of nuclear factor-kappa B (NF- $\kappa$ B) in IA formation and progression have been clarified and the potential of NF- $\kappa \mathrm{B}$ as a target for drug development of IAs is highlighted [22] [23]. NF- $\kappa \mathrm{B}$ is a master transcription factor regulating expressions of various pro-inflammatory genes and some of these NF- $\kappa \mathrm{B}$-regulated genes mediate inflammatory responses observed in IA lesions and contributing their pathogenesis such as IL-1 $\beta$ [28], matrix metalloproteinase (MMP-9) [21], cyclooxygenase-2 (COX-2) [24] and monocyte chemoattractant protein-1 (MCP-1) [20] [25]. In IAs, NF- $\kappa$ B is first activated in endothelial cells of intracranial arteries presumably through high wall shear stress [22], a putative trigger of IA formation [29]-[31], loaded on bifurcation sites of intracranial arteries where IAs develop in most cases. NF- $\kappa \mathrm{B}$, then, transcriptionally induces various pro-inflammatory genes in endothelial cells and, among them, MCP-1 is presumably most critical for IA formation [20] [25]. MCP-1 recruits macrophages in arterial walls and contributes to the exacerbation of macrophage-mediated inflammation mediated by a large amount of pro-inflammatory factors secreted from these cells such as cytokines like IL- $1 \beta$ and proteinases like MMP-9. In macrophages, NF- $\kappa \mathrm{B}$ is also activated and functions through regulating production of pro-inflammatory factors [22]. The critical role of NF- $\kappa$ B in the pathogenesis of IA formation and progression is clearly demonstrated from animal studies, in which the deficiency of NF- $\kappa \mathrm{B}$ p50 subunit in mice or the inhibition of transcriptional activity of NF- $\kappa \mathrm{B}$ by the use of decoy oligonucleotides [32] in rats significantly suppresses IA formation and progression through inhibiting inflammatory responses in lesions [22].

\section{Stains as a Potential Therapeutic Drugs for IA Treatment}

Recent experimental studies using animal models have proposed drugs with anti-inflammatory effect especially 
anti-NF- $\kappa$ B effect as potential therapeutic tools for IA treatment. Hydroxyl-3-methylglutaryl coenzyme A (HMG-CoA) reductase inhibitors, known as statins, are widely used as cholesterol-lowering drugs. In addition to their excellent cholesterol-lowering effect, statins have the potent anti-inflammatory and especially anti-NF- $\kappa \mathrm{B}$ effect, well known as "pleiotropic effect of statins" though precise mechanisms underlying their anti-inflammatory effect are not clear [33] [34]. In IAs, the administration of statins to rodent model elicits the beneficial effects [35]-[37] though only one report demonstrates the deleterious effect on IA progression [38] (Table 1). Three kinds of statins orally administered to rat model of IAs, pravastatin [35], simvastatin [36] or pitavastatin [37], significantly suppress the formation, progression or enlargement of induced IAs, independent of their cholesterol-lowering effects (Table 1). Furthermore, statins can effectively suppress the further enlargement of pre-existing IAs in these models [36] [37]. In IA lesions, statin treatment significantly suppress inflammatory responses including NF- $\kappa \mathrm{B}$ activation and subsequent expressions of pro-inflammatory factors as expected [36] [37]. One report demonstrates the exacerbation of apoptosis in IA walls and acceleration of IA progression by "high dose" pravastatin and simvastatin treatment in rat models [38], in opposite from results of other studies [35]-[37]. Because in this report, "low dose" pravastatin reduces endothelial cell damage in intracranial arteries in vivo and consistently, treatment of this drug in cultured endothelial cells dose-dependently increases eNOS expression and suppresses ICAM-1 expression in vitro, pravastatin has the protective and anti-inflammatory effects on endothelial cells [38]. Therefore, the deleterious effect of pravastatin and simvastatin may be due to the effect of these statins on other type of cells or depend on the dosage in lesions, although we cannot discuss the latter possibility because of the lack of data regarding serum statin concentration. Further, usage of different sexes in rat models used in these studies, male in [36] [37] and female in [38], may explain the differences.

Given the established safety of statins in humans and the excellent inhibitory effect on IA progression in rodent models (Table 1), statins may be promising drugs for IA treatment to prevent the progression and rupture in humans, and some other compound also can suppresses IA progression in rodent models mainly through their anti-inflammatory effects [39]-[43].

\section{Effect of Statins on IAs in Human Cases}

Regarding the incidence of IAs, one single-center case-control study demonstrates the independence from statin usage [44]. Total 300 IA patients (cases) and 900 controls were enrolled in this study and the association of statin usage with the incidence of IA was statistically analyzed [44]. Because in this study hypertension and smoking, which are established risk factors for IA development [45]-[47], were pick up as factors positively associated with the incidence of IAs with the odds ratio of 4.02 and 1.67, respectively [44], this study was appropriately done and results obtained seem to be authoritative. As statin usage had no effect on the incidence of IAs [44], statins do not appear to influence IA formation.

As for rupture, the most serious event relating IAs, a recent hospital-based case-control study has implicated the potential of statins as drugs to prevent rupture [48] (Table 2). In this study, 117 patients with ruptured IAs (subarachnoid hemorrhage) (cases) and 304 patients with unruptured IAs (controls) were enrolled from 15 institutes in Japan [48] (Table 2). Background characteristics of patients enrolled including age, sex, family history of subarachnoid hemorrhage were not different [48]. Because size of IAs and current smoking are properly identified as factors related with rupture of IAs consistent with previous report [46] [47] [49] [50] (Table 2), the results from this case-control study seems to be reliable. In this study, stains were used in 9.4\% of cases (11/117) and $26.0 \%$ in controls (79/304) and usage of statins between two groups reached statistically significant (p < 0.001) [48] (Table 2). Further, if the relationship between statin usage and rupture of IAs was analyzed after stratifying the data by serum cholesterol level, statin usage still inversely correlated with the risk of rupture of IAs in patients with serum cholesterol level of over $130 \mathrm{mg} / \mathrm{dL}$ [48]. Using logistic regression analysis, the usage of any statin was inversely correlated with rupture of IAs at the adjusted odds ratio of 0.30 [48]. Meanwhile, in this study, the protective effect of non-steroidal anti-inflammatory drugs on rupture of IAs was not shown ( $\mathrm{p}=0.39$ ) unlike the previous report [51] though exact reason of discrepancy is not clear.

From these studies, the potential of statins as therapeutic drugs for preventing rupture of IAs have been proposed. In this sense, statins may be a good candidate of drugs for patients with unruptured IAs and concomitant hypercholesterolemia. However, because statins can decrease serum cholesterol level even in healthy person through their potent cholesterol-lowing effect and hypercholesterolemia is not a risk factor of IAs, the safety of statins on patients without hypercholesterolemia, a major part of patient with IAs (about 74\% of patients with 
Table 1. The summary of the effect of statins in rat models of intracranial aneurysm.

\begin{tabular}{|c|c|c|c|c|c|c|}
\hline Drug & $\begin{array}{c}\text { Dose } \\
\text { (Administration method) }\end{array}$ & $\begin{array}{l}\text { Effect of statins on } \\
\text { intracranial aneurysm }\end{array}$ & $\begin{array}{l}\text { Animals } \\
\text { used }\end{array}$ & $\begin{array}{l}\text { Methods for induction } \\
\text { of aneurysm }\end{array}$ & $\begin{array}{c}1 \mathrm{st} \\
\text { Author }\end{array}$ & Journal \\
\hline & 25 mg/kg/day & $\begin{array}{l}\text { 1) Suppression of enlargement } \\
\text { of intracranial aneurysm }\end{array}$ & & High salt diet & & \\
\hline Simvastatin & (mixed in chow) & $\begin{array}{l}\text { 2) Suppression of further } \\
\text { enlargement of pre-existing } \\
\text { aneurysm }\end{array}$ & $\begin{array}{c}\text { male } \\
\text { rats }\end{array}$ & $\begin{array}{c}\text { Ligation of left common } \\
\text { carotid artery and posterior } \\
\text { branches of bilateral renal } \\
\text { arteries }\end{array}$ & Aoki T & $\begin{array}{l}\text { Stroke.2008; } \\
\text { 39:1276-1285. }\end{array}$ \\
\hline & $5 \mathrm{mg} / \mathrm{kg} /$ day & $\begin{array}{l}\text { 1) Suppression of enlargement } \\
\text { of aneurysm }\end{array}$ & & High salt diet & & \\
\hline Pitavastatin & (mixed in chow) & $\begin{array}{l}\text { 2) Suppression of further } \\
\text { enlargement of pre-existing } \\
\text { aneurysm }\end{array}$ & $\begin{array}{l}\text { male } \\
\text { rats }\end{array}$ & $\begin{array}{c}\text { Ligation of left common } \\
\text { carotid artery and posterior } \\
\text { branches of bilateral renal } \\
\text { arteries }\end{array}$ & Aoki T & $\begin{array}{c}\text { Neurosurgery. } \\
2009 ; \\
64: 357-365\end{array}$ \\
\hline \multirow{3}{*}{ Pravastatin } & 50 or $100 \mathrm{mg} / \mathrm{kg} /$ day & & & $\begin{array}{l}\text { Drinking water } \\
\text { containing } \\
1 \% \mathrm{NaCl}\end{array}$ & & \multirow{3}{*}{$\begin{array}{c}\text { Brain research. } \\
\text { 2010; } \\
\text { 1322:144-152 }\end{array}$} \\
\hline & (mixed in chow) & $\begin{array}{l}\text { Reduction of the ratio of } \\
\text { aneurysms in advanced stage }\end{array}$ & $\begin{array}{l}\text { female } \\
\text { rats }\end{array}$ & $\begin{array}{c}\text { Ligation of right common } \\
\text { carotid artery and posterior } \\
\text { branches of bilateral renal } \\
\text { arteries }\end{array}$ & $\begin{array}{c}\text { Kimura } \\
\mathrm{N}\end{array}$ & \\
\hline & & & & Bilateral oophorectomy & & \\
\hline \multirow[b]{2}{*}{ Pravastatin } & $5 \mathrm{mg} / \mathrm{kg} /$ day (gavage) & $\begin{array}{l}\text { Reduction of the ratio of } \\
\text { aneurysm formation }\end{array}$ & & $\begin{array}{c}\text { Drinking water } \\
\text { containing } 1 \% \mathrm{NaCl}\end{array}$ & \multirow{3}{*}{ Tada Y } & \multirow{3}{*}{$\begin{array}{l}\text { Stroke.2011; } \\
\text { 42:2286-2293 }\end{array}$} \\
\hline & $\begin{array}{l}25 \text { or } 50 \mathrm{mg} / \mathrm{kg} / \text { day } \\
\text { (gavage) }\end{array}$ & $\begin{array}{l}\text { Increase of the ratio of } \\
\text { aneurysm formation }\end{array}$ & $\begin{array}{l}\text { female } \\
\text { rats }\end{array}$ & $\begin{array}{l}\text { Ligation of left common } \\
\text { carotid artery and bilateral } \\
\text { posterior renal arteries }\end{array}$ & & \\
\hline Simvastatin & $5 \mathrm{mg} / \mathrm{kg} /$ day (gavage) & $\begin{array}{l}\text { Increase of the ratio of } \\
\text { aneurysm formation }\end{array}$ & & Bilateral oophorectomy & & \\
\hline
\end{tabular}

Table 2. The summary of recent reported case-control study regarding the effect of statin usage on rupture of pre-existing aneurysms in human.

\begin{tabular}{cccc} 
& \multicolumn{1}{c}{ Cases; } & Controls; & \multirow{2}{*}{ p value } \\
\cline { 2 - 3 } & Ruptured aneurysms & Un-ruptured aneurysms & \\
\cline { 2 - 3 } & $(\mathrm{n}=117)$ & $(\mathrm{n}=304)$ & n.s. \\
Age (years, mean (s.e.m)) & $60.46(13.77)$ & $64.34(11.33)$ & n.s. \\
Male (\%) & 35 & 34.2 & n.s. \\
Family history of SAH (\%) & 11.1 & 13.2 & $<0.01$ \\
Size (mm, mean (s.e.m)) & $6.4(3.40)$ & $5.1(3.20)$ & $<0.001$ \\
Current smoking (\%) & 31.6 & 13.5 & $<0.001$ \\
Statin use (\%) & 9.4 & 26 & \\
\hline
\end{tabular}

IAs from our study), is needed be established to warrant further randomized placebo-controlled study.

Aortic aneurysm is another category of aneurysm, characterized by the ectasia of aorta through the degenerative changes of aortic wall. The beneficial effect of statins through their pleiotropic anti-inflammatory effect is somewhat controversial even today [52]-[54] and, therefore, a high quality randomized control study should be done given the social loss due to this disease, same as a case in IAs. Under these circumstances, recent metaanalysis on the effect of statins on the enlargement of aortic aneurysm reported the beneficial trend of statin usage to prevent the enlargement [55]. Based on these findings together with those from IA researches, statins may be a good candidate of drugs for aneurysm treatments. 


\section{Conclusion}

IA is a chronic inflammatory disease in intracranial arteries mediated by NF- $\kappa$ B activation. Suppression of inflammation is, therefore, a reasonable strategy for IA treatment to prevent enlargement and rupture. Statins may be promising drugs for IA treatment through their potent anti-NF- $\kappa$ B effect.

\section{Acknowledgements}

Authors would like to express our sincere gratitude to all the researchers, collaborators, technical assistants and secretaries participating in our series of studies. Authors also express our gratitude to grants supporting our researches.

\section{Conflict of Interest Statement}

The authors declare that they have no conflict of interest.

\section{References}

[1] van Gijn, J., Kerr, R.S. and Rinkel, G.J. (2007) Subarachnoid Haemorrhage. Lancet, 369, 306-318. http://dx.doi.org/10.1016/S0140-6736(07)60153-6

[2] Wiebers, D.O., Piepgras, D.G., Brown Jr., R.D., Meissner, I., Torner, J., Kassell, N.F., Whisnant, J.P., Huston 3rd, J. and Nichols, D.A. (2002) Unruptured Aneurysms. Journal of Neurosurgery, 96, 50-51. http://dx.doi.org/10.3171/jns.2002.96.1.0050

[3] Rinkel, G.J., Djibuti, M., Algra, A. and van Gijn, J. (1998) Prevalence and Risk of Rupture of Intracranial Aneurysms: A Systematic Review. Stroke, 29, 251-256. http://dx.doi.org/10.1161/01.STR.29.1.251

[4] Steiner, T., Juvela, S., Unterberg, A., Jung, C., Forsting, M. and Rinkel, G. (2013) European Stroke Organization Guidelines for the Management of Intracranial Aneurysms and Subarachnoid Haemorrhage. Cerebrovascular Disease, 35, 93-112. http://dx.doi.org/10.1159/000346087

[5] Kotowski, M., Naggara, O., Darsaut, T.E., Nolet, S., Gevry, G., Kouznetsov, E. and Raymond, J. (2013) Safety and Occlusion Rates of Surgical Treatment of Unruptured Intracranial Aneurysms: A Systematic Review and Meta-Analysis of the Literature from 1990 to 2011. Journal of Neurology, Neurosurgery, and Psychiatry, 84, 42-48. http://dx.doi.org/10.1136/jnnp-2011-302068

[6] Naggara, O.N., Lecler, A., Oppenheim, C., Meder, J.F. and Raymond, J. (2012) Endovascular Treatment of Intracranial Unruptured Aneurysms: A Systematic Review of the Literature on Safety with Emphasis on Subgroup Analyses. Radiology, 263, 828-835. http://dx.doi.org/10.1148/radiol.12112114

[7] Chyatte, D., Bruno, G., Desai, S. and Todor, D.R. (1999) Inflammation and Intracranial Aneurysms. Neurosurgery, 45, 1137-1146. http://dx.doi.org/10.1097/00006123-199911000-00024

[8] Frosen, J., Piippo, A., Paetau, A., Kangasniemi, M., Niemela, M., Hernesniemi, J. and Jaaskelainen, J. (2004) Remodeling of Saccular Cerebral Artery Aneurysm Wall Is Associated with Rupture: Histological Analysis of 24 Unruptured and 42 Ruptured Cases. Stroke, 35, 2287-2293. http://dx.doi.org/10.1161/01.STR.0000140636.30204.da

[9] Fontanella, M., Rainero, I., Gallone, S., Rubino, E., Fenoglio, P., Valfre, W., Garbossa, D., Carlino, C., Ducati, A. and Pinessi, L. (2007) Tumor Necrosis Factor-Alpha Gene and Cerebral Aneurysms. Neurosurgery, 60, 668-672. http://dx.doi.org/10.1227/01.NEU.0000255417.93678.49

[10] Jayaraman, T., Berenstein, V., Li, X., Mayer, J., Silane, M., Shin, Y.S., Niimi, Y., Kilic, T., Gunel, M. and Berenstein, A. (2005) Tumor Necrosis Factor Alpha Is a Key Modulator of Inflammation in Cerebral Aneurysms. Neurosurgery, 57, 558-564. http://dx.doi.org/10.1227/01.NEU.0000170439.89041.D6

[11] Kataoka, H. and Aoki, T. (2010) Molecular Basis for the Development of Intracranial Aneurysm. Expert Review of Neurotherapeutics, 10, 173-187. http://dx.doi.org/10.1586/ern.09.155

[12] Kurki, M.I., Hakkinen, S.K., Frosen, J., Tulamo, R., von und zu Fraunberg, M., Wong, G., Tromp, G., Niemela, M., Hernesniemi, J., Jaaskelainen, J.E. and Yla-Herttuala, S. (2011) Upregulated Signaling Pathways in Ruptured Human Saccular Intracranial Aneurysm Wall: An Emerging Regulative Role of Toll-Like Receptor Signaling and Nuclear Factor-Kappa B, Hypoxia-Inducible Factor-1A, and ETS Transcription Factors. Neurosurgery, 68, 1667-1675. http://dx.doi.org/10.1227/NEU.0b013e318210f001

[13] Shi, C., Awad, I.A., Jafari, N., Lin, S., Du, P., Hage, Z.A., Shenkar, R., Getch, C.C., Bredel, M., Batjer, H.H. and Bendok, B.R. (2009) Genomics of Human Intracranial Aneurysm Wall. Stroke, 40, 1252-1261. http://dx.doi.org/10.1161/STROKEAHA.108.532036 
[14] Laaksamo, E., Tulamo, R., Baumann, M., Dashti, R., Hernesniemi, J., Juvela, S., Niemela, M. and Laakso, A. (2008) Involvement of Mitogen-Activated Protein Kinase Signaling in Growth and Rupture of Human Intracranial Aneurysms. Stroke, 39, 886-892. http://dx.doi.org/10.1161/STROKEAHA.107.497875

[15] Laaksamo, E., Tulamo, R., Liiman, A., Baumann, M., Friedlander, R.M., Hernesniemi, J., Kangasniemi, M., Niemela, M., Laakso, A. and Frosen, J. (2013) Oxidative Stress Is Associated with Cell Death, Wall Degradation, and Increased Risk of Rupture of the Intracranial Aneurysm Wall. Neurosurgery, 72, 109-117. http://dx.doi.org/10.1227/NEU.0b013e3182770e8c

[16] Krischek, B., Kasuya, H., Tajima, A., Akagawa, H., Sasaki, T., Yoneyama, T., Ujiie, H., Kubo, O., Bonin, M., Takakura, K., Hori, T. and Inoue, I. (2008) Network-Based Gene Expression Analysis of Intracranial Aneurysm Tissue Reveals Role of Antigen Presenting Cells. Neuroscience, 154, 1398-1407. http://dx.doi.org/10.1016/j.neuroscience.2008.04.049

[17] Tulamo, R., Frosen, J., Junnikkala, S., Paetau, A., Pitkaniemi, J., Kangasniemi, M., Niemela, M., Jaaskelainen, J., Jokitalo, E., Karatas, A., Hernesniemi, J. and Meri, S. (2006) Complement Activation Associates with Saccular Cerebral Artery Aneurysm Wall Degeneration and Rupture. Neurosurgery, 59, 1069-1076.

[18] Hashimoto, N., Handa, H. and Hazama, F. (1978) Experimentally Induced Cerebral Aneurysms in Rats. Surgical Neurology, 10, 3-8.

[19] Aoki, T. and Nishimura, M. (2011) The Development and the Use of Experimental Animal Models to Study the Underlying Mechanisms of CA Formation. Journal of Biomedicine \& Biotechnology, 2011, Article ID: 535921. http://dx.doi.org/10.1155/2011/535921

[20] Aoki, T., Kataoka, H., Ishibashi, R., Nozaki, K., Egashira, K. and Hashimoto, N. (2009) Impact of Monocyte Chemoattractant Protein-1 Deficiency on Cerebral Aneurysm Formation. Stroke, 40, 942-951. http://dx.doi.org/10.1161/STROKEAHA.108.532556

[21] Aoki, T., Kataoka, H., Morimoto, M., Nozaki, K. and Hashimoto, N. (2007) Macrophage-Derived Matrix Metalloproteinase-2 and -9 Promote the Progression of Cerebral Aneurysms in Rats. Stroke, 38, 162-169. http://dx.doi.org/10.1161/01.STR.0000252129.18605.c8

[22] Aoki, T., Kataoka, H., Shimamura, M., Nakagami, H., Wakayama, K., Moriwaki, T., Ishibashi, R., Nozaki, K., Morishita, R. and Hashimoto, N. (2007) NF- $\kappa$ B Is a Key Mediator of Cerebral Aneurysm Formation. Circulation, 116, 2830-2840. http://dx.doi.org/10.1161/CIRCULATIONAHA.107.728303

[23] Aoki, T. and Nishimura, M. (2010) Targeting Chronic Inflammation in Cerebral Aneurysms: Focusing on NF- $\kappa$ B as a Putative Target of Medical Therapy. Expert Opinion on Therapeutic Targets, 14, 265-273. http://dx.doi.org/10.1517/14728221003586836

[24] Aoki, T., Nishimura, M., Matsuoka, T., Yamamoto, K., Furuyashiki, T., Kataoka, H., Kitaoka, S., Ishibashi, R., Ishibazawa, A., Miyamoto, S., Morishita, R., Ando, J., Hashimoto, N., Nozaki, K. and Narumiya, S. (2011) PGE $-E_{2} P_{2}$ Signalling in Endothelium Is Activated by Haemodynamic Stress and Induces Cerebral Aneurysm through an Amplifying Loop via NF- $\kappa$ B. British Journal of Pharmacology, 163, 1237-1249. http://dx.doi.org/10.1111/j.1476-5381.2011.01358.x

[25] Kanematsu, Y., Kanematsu, M., Kurihara, C., Tada, Y., Tsou, T.L., van Rooijen, N., Lawton, M.T., Young, W.L., Liang, E.I., Nuki, Y. and Hashimoto, T. (2011) Critical Roles of Macrophages in the Formation of Intracranial Aneurysm. Stroke, 42, 173-178. http://dx.doi.org/10.1161/STROKEAHA.110.590976

[26] Fukuda, S., Hashimoto, N., Naritomi, H., Nagata, I., Nozaki, K., Kondo, S., Kurino, M. and Kikuchi, H. (2000) Prevention of Rat Cerebral Aneurysm Formation by Inhibition of Nitric Oxide Synthase. Circulation, 101, 2532-2538. http://dx.doi.org/10.1161/01.CIR.101.21.2532

[27] Sadamasa, N., Nozaki, K. and Hashimoto, N. (2003) Disruption of Gene for Inducible Nitric Oxide Synthase Reduces Progression of Cerebral Aneurysms. Stroke, 34, 2980-2984. http://dx.doi.org/10.1161/01.STR.0000102556.55600.3B

[28] Moriwaki, T., Takagi, Y., Sadamasa, N., Aoki, T., Nozaki, K. and Hashimoto, N. (2006) Impaired Progression of Cerebral Aneurysms in Interleukin-1 $\beta$-Deficient Mice. Stroke, 37, 900-905. http://dx.doi.org/10.1161/01.STR.0000204028.39783.d9

[29] Dolan, J.M., Kolega, J. and Meng, H. (2013) High Wall Shear Stress and Spatial Gradients in Vascular Pathology: A Review. Annals of Biomedical Engineering, 41, 1411-1427. http://dx.doi.org/10.1007/s10439-012-0695-0

[30] Jou, L.D., Lee, D.H., Morsi, H. and Mawad, M.E. (2008) Wall Shear Stress on Ruptured and Unruptured Intracranial Aneurysms at the Internal Carotid Artery. AJNR. American Journal of Neuroradiology, 29, 1761-1767. http://dx.doi.org/10.3174/ajnr.A1180

[31] Takeuchi, S. and Karino, T. (2010) Flow Patterns and Distributions of Fluid Velocity and Wall Shear Stress in the Human Internal Carotid and Middle Cerebral Arteries. World Neurosurgery, 73, 174-185.

[32] Morishita, R., Tomita, N., Kaneda, Y. and Ogihara, T. (2004) Molecular Therapy to Inhibit NF- $\kappa$ B Activation by 
Transcription Factor Decoy Oligonucleotides. Current Opinion in Pharmacology, 4, 139-146. http://dx.doi.org/10.1016/j.coph.2003.10.008

[33] Bellosta, S., Bernini, F., Ferri, N., Quarato, P., Canavesi, M., Arnaboldi, L., Fumagalli, R., Paoletti, R. and Corsini, A. (1998) Direct Vascular Effects of HMG-CoA Reductase Inhibitors. Atherosclerosis, 137, 101-109. http://dx.doi.org/10.1016/S0021-9150(97)00319-5

[34] Shovman, O., Levy, Y., Gilburd, B. and Shoenfeld, Y. (2002) Antiinflammatory and Immunomodulatory Properties of Statins. Immunologic Research, 25, 271-285. http://dx.doi.org/10.1385/IR:25:3:271

[35] Kimura, N., Shimizu, H., Eldawoody, H., Nakayama, T., Saito, A., Tominaga, T. and Takahashi, A. (2010) Effect of Olmesartan and Pravastatin on Experimental Cerebral Aneurysms in Rats. Brain Research, 1322, 144-152. http://dx.doi.org/10.1016/j.brainres.2010.01.044

[36] Aoki, T., Kataoka, H., Ishibashi, R., Nozaki, K. and Hashimoto, N. (2008) Simvastatin Suppresses the Progression of Experimentally Induced Cerebral Aneurysms in Rats. Stroke, 39, 1276-1285. http://dx.doi.org/10.1161/STROKEAHA.107.503086

[37] Aoki, T., Kataoka, H., Ishibashi, R., Nakagami, H., Nozaki, K., Morishita, R. and Hashimoto, N. (2009) Pitavastatin Suppresses Formation and Progression of Cerebral Aneurysms through Inhibition of the Nuclear Factor $\kappa \mathrm{B}$ Pathway. Neurosurgery, 64, 357-366. http://dx.doi.org/10.1227/01.NEU.0000336764.92606.1D

[38] Tada, Y., Kitazato, K.T., Yagi, K., Shimada, K., Matsushita, N., Kinouchi, T., Kanematsu, Y., Satomi, J., Kageji, T. and Nagahiro, S. (2011) Statins Promote the Growth of Experimentally Induced Cerebral Aneurysms in Estrogen-Deficient Rats. Stroke, 42, 2286-2293. http://dx.doi.org/10.1161/STROKEAHA.110.608034

[39] Aoki, T., Kataoka, H., Ishibashi, R., Nozaki, K. and Hashimoto, N. (2008) Nifedipine Inhibits the Progression of an Experimentally Induced Cerebral Aneurysm in Rats with Associated Down-Regulation of NF- $\kappa$ B Transcriptional Activity. Current Neurovascular Research, 5, 37-45. http://dx.doi.org/10.2174/156720208783565663

[40] Ishibashi, R., Aoki, T., Nishimura, M. and Miyamoto, S. (2012) Imidapril Inhibits Cerebral Aneurysm Formation in an Angiotensin-Converting Enzyme-Independent and Matrix Metalloproteinase-9-Dependent Manner. Neurosurgery, 70, 722-730. http://dx.doi.org/10.1227/NEU.0b013e3182326188

[41] Ishibashi, R., Aoki, T., Nishimura, M., Hashimoto, N. and Miyamoto, S. (2010) Contribution of Mast Cells to Cerebral Aneurysm Formation. Current Neurovascular Research, 7, 113-124. http://dx.doi.org/10.2174/156720210791184916

[42] Tada, Y., Kitazato, K.T., Tamura, T., Yagi, K., Shimada, K., Kinouchi, T., Satomi, J. and Nagahiro, S. (2009) Role of Mineralocorticoid Receptor on Experimental Cerebral Aneurysms in Rats. Hypertension, 54, 552-557. http://dx.doi.org/10.1161/HYPERTENSIONAHA.109.134130

[43] Yagi, K., Tada, Y., Kitazato, K.T., Tamura, T., Satomi, J. and Nagahiro, S. (2010) Ibudilast Inhibits Cerebral Aneurysms by Down-Regulating Inflammation-Related Molecules in the Vascular Wall of Rats. Neurosurgery, 66, 551-559. http://dx.doi.org/10.1227/01.NEU.0000365771.89576.77

[44] Marbacher, S., Schlappi, J.A., Fung, C., Husler, J., Beck, J. and Raabe, A. (2012) Do Statins Reduce the Risk of Aneurysm Development? A Case-Control Study. Journal of Neurosurgery, 116, 638-642. http://dx.doi.org/10.3171/2011.10.JNS11153

[45] Juvela, S., Poussa, K. and Porras, M. (2001) Factors Affecting Formation and Growth of Intracranial Aneurysms: A Long-Term Follow-Up Study. Stroke, 32, 485-491. http://dx.doi.org/10.1161/01.STR.32.2.485

[46] Kurth, T., Kase, C.S., Berger, K., Schaeffner, E.S., Buring, J.E. and Gaziano, J.M. (2003) Smoking and the Risk of Hemorrhagic Stroke in Men. Stroke, 34, 1151-1155. http://dx.doi.org/10.1161/01.STR.0000065200.93070.32

[47] Sandvei, M.S., Romundstad, P.R., Muller, T.B., Vatten, L. and Vik, A. (2009) Risk Factors for Aneurysmal Subarachnoid Hemorrhage in a Prospective Population Study: The HUNT Study in Norway. Stroke, 40, 1958-1962. http://dx.doi.org/10.1161/STROKEAHA.108.539544

[48] Yoshimura, Y., Murakami, Y., Saitoh, M., Yokoi, T., Aoki, T., Miura, K., Ueshima, H. and Nozaki, K. (2014) Statin Use and Risk of Cerebral Aneurysm Rupture: A Hospital-Based Case-Control Study in Japan. Journal of Stroke and Cerebrovascular Diseases, 23, 343-348. http://dx.doi.org/10.1016/j.jstrokecerebrovasdis.2013.04.022

[49] Morita, A., Kirino, T., Hashi, K., Aoki, N., Fukuhara, S., Hashimoto, N., Nakayama, T., Sakai, M., Teramoto, A., Tominari, S. and Yoshimoto, T. (2012) The Natural Course of Unruptured Cerebral Aneurysms in a Japanese Cohort. New England Journal of Medicine, 366, 2474-2482. http://dx.doi.org/10.1056/NEJMoa1113260

[50] Greving, J.P., Wermer, M.J., Brown Jr., R.D., Morita, A., Juvela, S., Yonekura, M., Ishibashi, T., Torner, J.C., Nakayama, T., Rinkel, G.J. and Algra, A. (2014) Development of the PHASES Score for Prediction of Risk of Rupture of Intracranial Aneurysms: A Pooled Analysis of Six Prospective Cohort Studies. Lancet Neurology, 13, 59-66. http://dx.doi.org/10.1016/S1474-4422(13)70263-1

[51] Hasan, D.M., Mahaney, K.B., Brown Jr., R.D., Meissner, I., Piepgras, D.G., Huston, J., Capuano, A.W. and Torner, J.C. (2011) Aspirin as a Promising Agent for Decreasing Incidence of Cerebral Aneurysm Rupture. Stroke, 42, 3156- 
3162. http://dx.doi.org/10.1161/STROKEAHA.111.619411

[52] Schouten, O., van Laanen, J.H., Boersma, E., Vidakovic, R., Feringa, H.H., Dunkelgrun, M., Bax, J.J., Koning, J., van Urk, H. and Poldermans, D. (2006) Statins Are Associated with a Reduced Infrarenal Abdominal Aortic Aneurysm Growth. European Journal of Vascular and Endovascular Surgery, 32, 21-26. http://dx.doi.org/10.1016/j.ejvs.2005.12.024

[53] Periard, D., Guessous, I., Mazzolai, L., Haesler, E., Monney, P. and Hayoz, D. (2012) Reduction of Small Infrarenal Abdominal Aortic Aneurysm Expansion Rate by Statins. VASA. Zeitschrift fur Gefasskrankheiten, 41, 35-42.

[54] Twine, C.P. and Williams, I.M. (2011) Systematic Review and Meta-Analysis of the Effects of Statin Therapy on Abdominal Aortic Aneurysms. British Journal of Surgery, 98, 346-353. http://dx.doi.org/10.1002/bjs.7343

[55] Takagi, H., Yamamoto, H., Iwata, K., Goto, S. and Umemoto, T. (2012) Effects of Statin Therapy on Abdominal Aortic Aneurysm Growth: A Meta-Analysis and Meta-Regression of Observational Comparative Studies. European Journal of Vascular and Endovascular Surgery, 44, 287-292. http://dx.doi.org/10.1016/j.ejvs.2012.06.021 
Scientific Research Publishing (SCIRP) is one of the largest Open Access journal publishers. It is currently publishing more than 200 open access, online, peer-reviewed journals covering a wide range of academic disciplines. SCIRP serves the worldwide academic communities and contributes to the progress and application of science with its publication.

Other selected journals from SCIRP are listed as below. Submit your manuscript to us via either submit@scirp.org or Online Submission Portal.
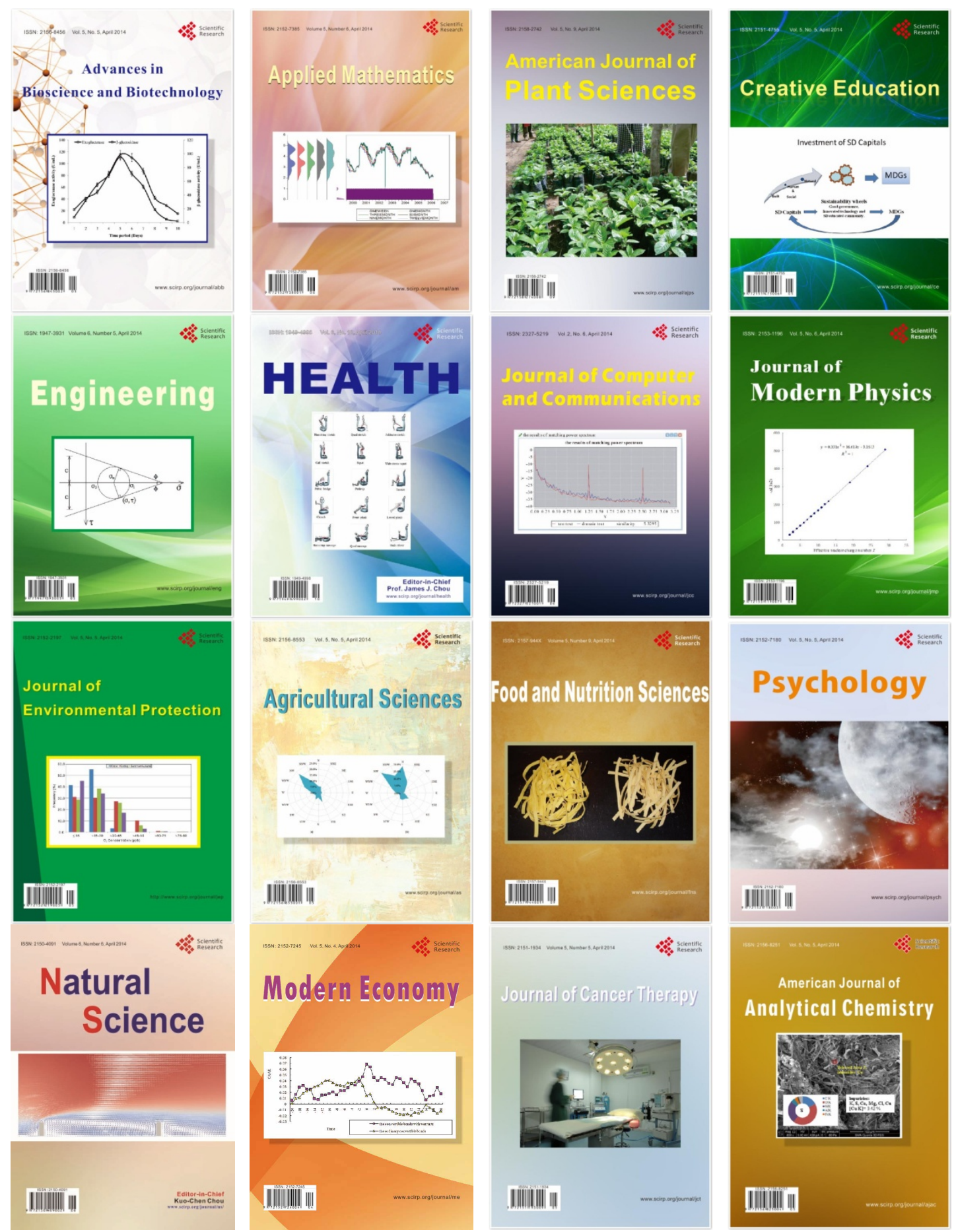